\title{
WP 03_11
}

\author{
Pierre L. Siklos \\ Wilfrid Laurier University, Canada \\ The Rimini Centre for Economic Analysis (RCEA), Italy
}

\section{EMERGING MARKET YIELD SPREADS: DOMESTIC, EXTERNAL DETERMINANTS, AND VOLATILITY SPILLOVERS}

Copyright belongs to the author. Small sections of the text, not exceeding three paragraphs, can be used provided proper acknowledgement is given.

The Rimini Centre for Economic Analysis (RCEA) was established in March 2007. RCEA is a private, nonprofit organization dedicated to independent research in Applied and Theoretical Economics and related fields. RCEA organizes seminars and workshops, sponsors a general interest journal The Review of Economic Analysis, and organizes a biennial conference: The Rimini Conference in Economics and Finance (RCEF) . The RCEA has a Canadian branch: The Rimini Centre for Economic Analysis in Canada (RCEACanada). Scientific work contributed by the RCEA Scholars is published in the RCEA Working Papers and Professional Report series.

The views expressed in this paper are those of the authors. No responsibility for them should be attributed to the Rimini Centre for Economic Analysis. 


\title{
EMERGING MARKET YIELD SPREADS: DOMESTIC, EXTERNAL DETERMINANTS, AND VOLATILITY SPILLOVERS*
}

\author{
Pierre L. Siklos \\ Wilfrid Laurier University \\ Waterloo, ON \\ Canada \\ and \\ Viessmann European Research Centre
}

[This Draft: October 2010]

\begin{abstract}
* Research for this paper was partly carried out while I was a visiting fellow at the Hong Kong Institute for Economic Research in 2007 and 2010 and Williams Evans Fellow at the University of Otago, New Zealand. I am grateful to the HKIMR for their hospitality, to Kenneth Chow for assistance in obtaining some of the data used in the empirical analysis, and to three anonymous referees for comments on a previous draft.
\end{abstract}


This study examines the determinants of bond yield spreads for 22 emerging markets in the period 1998-2009. In addition to the usual EMBI index data from credit default swaps (CDS) are also used. Three sets of determinants are considered: domestic, external, and institutional factors. In addition, I consider the connection between volatility and bond yield spreads. Volatility, and central bank transparency, are two factors common to all countries examined whereas clear idiosyncrasies are found according to whether emerging markets are in Latin and South America, Europe, Asia or Africa. Most notably, the global financial financial crisis did not impact yield spreads in Asia which suggests that, in a sense, bond markets in that region were decoupled from those in other parts of the world.

Keywords: emerging markets, yield spreads, volatility, transparency

JEL Classification codes: G15, C2, F34, F44

Pierre L. Siklos, Department of Economics

Wilfrid Laurier University, 75 University Ave. W.

Waterloo, ON Canada N2L 3C5

email:psiklos@wlu.ca

Web: www.wlu.ca/sbe/psiklos

Phone: +1 $5198841970 \times 2491$

Fax: +1 5198845922 


\section{Introduction}

The issuance of emerging market sovereign bonds surged during the 1990s, triggered by the Brady rescheduling agreement of the late 1980s. Financial crises during the 1990s, most notably the Mexican 'tequila' crisis of 1994-95, the Asian crisis of 1997-98, the Russian crisis of 1998, and the Argentine crisis of 2000-2001, led several economists to investigate the determinants of spreads between emerging market bond yields and those of comparable instruments issued by the U.S. government. The global financial crisis of 2008-9 adds yet another milestone in events that potentially influenced yield spreads. Perhaps unsurprisingly, opinion is divided about the role of economic 'fundamentals' in explaining movements in these spreads over time. Nevertheless, if fundamentals do matter and, just as importantly, if a set of common economic factors exist that have significant explanatory power in the determination of these spreads, then there are clear policy implications that can be drawn. A related question is the role played by economic shocks that influence emerging market bond spreads more or less simultaneously. This raises the possibility of spillover or contagion type effects. As is well-known, there is no universally accepted definition of contagion, though several metrics have been proposed in the literature. ${ }^{1} \mathrm{I}$ also address this issue, albeit in an indirect fashion, in this paper. Contagion effects are relevant since, for example, a post-mortem of the Asian crisis (e.g., BIS 1999) suggests that the transmission of financial shocks across countries, in some instances, took place over a period of several months, in part owing to infrequent adjustment of credit ratings (also see Remolona, Scatigna, and Wu 2006).

The aim of this study is to contribute to the literature on the determinants of emerging market bond spreads. One feature of this study consists in permitting volatility to directly influence yield spreads. The volatility index derived from the S\&P 500 group of stocks, also known as the VIX, is added (also see IMF 2006). In view of the rise in volatility of equity prices during the 2008-9 financial crisis, the

\footnotetext{
${ }^{1} \mathrm{~A}$ useful recent review of contagion versus interdependence hypotheses (also, see below) is Dungey, Fry, and Martin (2009).
} 
addition of more recent data may provide new insights into the role of asset price volatility on bond yield spreads.

Next, I add a time series indicator of central bank transparency. For reasons explained below, the relevant index captures many features present in alternative indicators of institutional performance and may well be a better way of capturing the relationship between the conduct of monetary policy and the behavior of term spreads. Third, this paper also employs yields derived from credit default swaps (CDS), for a subset of countries, to investigate the role of economic fundamentals in explaining emerging market bond yield spreads. Relatively few studies have considered this possibility (Remolona, Scatigna, and Wu (2006), and Ammer and Cai (2007) are exceptions), and none, to my knowledge, in the panel framework. In another departure from many other studies in the extant literature, I also consider forecasts of inflation, economic growth, and the current account, as potential determinants of such spreads. It is surprising that such forward-looking variables have not been considered more often in the relevant literature. After all, economic theory suggests that sovereign bond spreads ought to contain a forward-looking component and there is, of course, a large literature that considers whether the slope of the yield curve can reasonably predict future inflation, output growth, or even the likelihood of a recession (e.g., see Hamilton and Kim 2002). Moreover, it also pointed out that there is scope for nonlinearities in the determination of emerging market bond yield spreads. This is illustrated by permitting a key macroeconomic indicator, namely inflation forecasts, to asymmetrically influence yield spreads. Finally, explicit account is taken of the global financial crisis of 2008-9. As such, this study is the first one I am aware of that quantifies the impact of this event in yield spreads across various regions of the world.

I also estimate a modified pooled panel GARCH model (e.g., as in Cermeño and Grier 2005) to yield spreads. Typically, the extant literature relies on univariate time series models of bond spreads of the $\operatorname{GARCH}(1,1)$ variety. Unfortunately, as we shall see, none of the multivariate GARCH models 
considered produced satisfactory results. Part of the problem is the relatively small sample, and reliance on quarterly data. ${ }^{2}$ Alternatives, such as an $\operatorname{EGARCH}(1,1)$ model which permit asymmetric responses, are also not found to perform well.

Briefly, I find that the global financial crisis raised yield spreads in all regions except Asia and Africa, giving some credence to the decoupling view in the case of interest rate developments. It is also found that central bank transparency and changes in risk aversion are also significant determinants overall as well as across most regions considered. U.S. monetary policy impacts only Latin, South American and Asian economies in the sample. Finally, forward-looking variables, such as inflation and current account balance forecasts, are also significant determinants of emerging market yield spreads.

The rest of the paper consists of section 2 which provides a literature review, focusing on studies that rely on quarterly or monthly data. ${ }^{3}$ Section 3 describes the data and provides some stylized facts, as well as outlining the econometric methodology employed in the papers. Section 4 describes the empirical results while section 5 concludes.

\section{Literature Review}

In theory, the spread between emerging market bonds over U.S. Treasuries seeks to compensate investors in part for assuming a greater default risk. ${ }^{4}$ The probability of default is exogenously determined and inherently tied to the sustainability of a given level of debt and, hence, to a set of macroeconomic fundamentals (Ferrucci 2003). The drawback with this interpretation is that the impact of any contagion style effects may be unaccounted for. One definition of contagion refers to a

\footnotetext{
${ }^{2}$ Unfortunately, as we shall see, none of the multivariate GARCH models considered produced satisfactory results. Part of the problem is the relatively small number of observations in each cross-section. Another potential culprit is the reliance on quarterly data.

${ }^{3}$ There is a burgeoning literature that relies on daily data (e.g., Benelli and Ganguly 2007, and references therein). At the daily frequency the role of conventional macroeconomic fundamentals cannot be easily investigated. ${ }^{4}$ Liquidity risk is also present. However, the data used in the paper only includes bonds with a liquid market rendering the measurement of a liquidity premium less relevant for this type of analysis. Moreover, Remolona, Scatigna, and $\mathrm{Wu}$ (2006) report that default risk is the largest risk component in sovereign spreads. Hartelius, Kashiwase, and Kodres (2008) also conclude that liquidity effects are modest in the emerging markets bond market.
} 
significant increase in cross-market asset linkages following a shock to an individual country, or groups of countries (Forbes and Rigobon 2002). Hence, in calmer times, co-movements do not reflect contagion effects. This is a potentially relevant consideration as the sample overlaps with the period of the socalled 'Great Moderation' in the United States (e.g., Bernanke 2004).

Two different types of studies have explored how fundamentals explain emerging market bond spreads. They are: panel versus country-specific investigations. In the main, the latter set of studies rely on univariate time series models of spread behavior. Rowland and Torres (2004), however, is an example of a study that argues in favor of panel estimation. First, panels help to identify patterns in the data that are not easily captured using only time series or cross-section data. Second, the inclusion of both time series and cross-section data in panel data models controls for country-specific heterogeneity. Third, panel data estimation incorporates more information, greater variability, and can provide more efficient point estimates. Variations in the spread can also be decomposed into variability between groups of countries with similar characteristics, or groups of countries with different characteristics. Finally, panel data models can also be more efficient at estimating inter-temporal relations and, therefore, are better able to capture the dynamics of some adjustment process. While the panel approach has definite advantages there is disagreement on the preferred way to estimate them, including the need to difference the series prior to estimation. Taking first differences, and taking account of possible cointegration in the data, seems sensible both on statistical and economic grounds. However, the existing literature has not justified why several of the macroeconomic determinants of bond spreads should be cointegrated. Moreover, the span of data is often short enough so that it is unlikely that reliable long run relationships between the variables of interest can be adequately detected. 
Time series models have their own appeal, especially when multivariate extensions to widely used GARCH-type models of conditional volatility are estimated, unless one is unable to restrict what would otherwise result in a dramatic increase in the number of parameters that must be estimated. It is impractical to review all the contributions to this literature that has experienced a revival of interest since the early part of the 2000s, when a flurry of studies on the determinants of emerging market bond spreads were published. A partial list would include Hartelius, Kaniwashe, and Kodres (2008), Frank and Hesse (2009), Ferrucci (2003), Grandes (2003), Rozada and Levy-Yeyati (2006), Andritszky, Bannister and Tarmirisa (2005), and Garcia-Herrero and Ortiz (2004). Well-known earlier studies in the literature include Edwards $(1984,1986)$, Sachs, Tornell and Velasco (1996), and Eichengreen and Mody (2000).

One difficulty in assessing the state of the literature stems from the terminology used to describe models and their motivation. Some authors refer to a "monsoon effect" (e.g., Masson and Mussa 1995) to capture the impact of economic or financial crisis might have across several countries at once. Others refer to "spillover" effects (Calvo and Reinhart 1996), wherein a crisis in one emerging market influences fundamentals elsewhere, resulting in a form of collateral damage. Still others refer to contagion effects (or "pure" contagion) to capture the possibility that a crisis in one emerging market can produce a crisis elsewhere without going through any of the usual economic fundamentals (e.g., Sachs, et.al. 1996). ${ }^{5}$ The nomenclature used to describe the determinants of emerging market bond spreads has continued to expand. Thus, for example, some research has delineated spillover effects in the conditional mean of yield spreads while ignoring or downplaying the spread of volatility shocks. For volatility spillovers one must be aware of a distinction that exists between 'heat waves' and 'meteor showers'. The latter refers to volatility spillovers from one country to the next while the former captures volatility with only country-specific shocks. More recently, there are references to "push" and "pull" factors, the former representing country-specific forces while the latter captures the role of global

\footnotetext{
${ }^{5}$ http://go.worldbank.org/JIBDRK3YCO is a source that contains a compendium of different meanings attached to the concept of 'contagion'.
} 
factors on bond yields (e.g., Ciarlone, Piselli and Trebischi 2007). As Dailami, Masson, and Padou (2005) note, it is difficult conceptually to differentiate pull from push factors, especially since there is likely an endogenous relationship between domestic and international effects on movements in bond spreads. Some authors find U.S. monetary policy plays a significant role (e.g., Arora and Cerisola 2000, Min et al. 2003, Ferrucci et al. 2004) while others have expressed reservations about the importance of U.S. shocks (e.g., Kamin and von Kleist 1999, Eichengreen and Mody 2000). As noted above, part of the disagreement may stem from the choice of sample period, sampling frequency, and the methodological approach used to investigate the determinants of emerging market yield spreads.

There are also questions that stem from attempts to distinguish between types of crises. Some are banking related others are currency related, to give just two examples. Difficulties in identifying the precise sources of these crises are well-known (e.g., Kaminsky 2003, Pericoli and Sbracia 2003). Nevertheless, the crises that are likely more germane to the empirical analysis of this paper are likely of the financial variety, as noted in the introduction. In this connection, extensions of the dataset to incorporate a role for the so-called global financial crisis of 2008-9 should represent a useful addition to the debate about what moves emerging market yield spreads.

It is also rather difficult to provide a concise list of so-called fundamentals that are reliably related to movements in emerging market bond yield spreads. Such a list would include, in no particular order of importance, exchange rates, interest rates, exports, inflation, oil prices, foreign exchange reserves, foreign direct investment, the degree of financial development, and the current account. It is interesting that the literature linking macroeconomic fundamentals to emerging market bond yields does not fully take advantage of the distinctiveness of business cycles in emerging market relative to ones in industrialized economies. Most notably, emerging markets have, except perhaps in the last few years, occasionally experienced 'sudden stops'. These refer to fairly brief but sharp interruptions in economic activity that have attracted considerable attention in the literature (e.g., see Calvo 2003, and 
Christiano, Gust and Roldos 2002). Asymmetry, or possible non-linearity, in business cycles in emerging markets has not been exploited more fully in the empirical literature. As will be seen below, asymmetries may well play a significant role in explaining emerging market yield spreads. Finally, it is surprising that more use has not been made of certain institutional developments to explain movements in emerging market yield spreads, such as the drive to emphasize and improve central bank transparency. As far as I am aware the present study of the first one to do so.

Several studies of the determinants of bond yield spreads in emerging markets tend to focus on the Latin and South American experience not only because the data are relatively more plentiful but also because several of the crises that warranted attention in the literature originated or spilled over into that part of the world. More recently, attention has turned to the experience of emerging market economies in Europe and Asia (e.g., Baig and Goldfajn 1999, Debelle and Ellis 2005, Sander and Kleinmeier 2003). Finally, there exists a fair amount of diversity in the methodological approaches used to investigate the cross-section or time series behavior of term spreads. These range from the 'adjusted' correlations of Forbes and Rigobon (2002), varieties of conditional volatility models (e.g., see Arora and Cerisola 2001), dynamic conditional correlation analysis (e.g., Chiang, Jeon, and Li 2007), extreme value models (e.g., Longin and Solnik 2001), through to factor analysis (e.g., Dungey, Fry, Gonzales-Hermosillo, and Martin 2004). ${ }^{6}$

While there exists a range of opinions about what drives emerging market bond yield spreads, a few broad conclusions can be drawn from the foregoing select overview of the literature. First, even if it is unclear which economic 'fundamentals' matter most, the presence of strong fundamentals does appear to contribute to influencing yield spreads. Second, trade and financial linkages between countries play a significant role, as does proximity to the source of a particular crisis. Third, there is reasonably persuasive evidence that a crisis originating in a developed economy can, and does, spillover

\footnotetext{
${ }^{6}$ A separate literature, from the perspective of this study, are papers that estimate the probability of a crisis using logit, probit, or Markov switching models. See Pericoli and Sbracia (2003) for a survey.
} 
into emerging markets. Nevertheless, the presence of strong fundamentals can protect, if not shield, an emerging market from crises elsewhere, as we shall see.

\section{Data and Model Specification}

\subsection{Data}

Since many of the macroeconomic fundamentals (e.g., GDP, price level) are only available at the quarterly sampling frequency, and only since the mid 1990s for several of the countries in the sample, the empirical evidence reported below relies on data covering the 1996Q1-2009Q4 period before any transformations are made to the data. ${ }^{7}$ A total of 22 countries are considered. Eight countries are in Latin and South America (Argentina, Brazil, Colombia, Ecuador, Mexico, Panama, Peru, Venezuela), five are from Europe (Bulgaria, Poland, Russia, Turkey, Ukraine), four from Africa (Egypt, Morocco, Nigeria, South Africa), and five are from Asia (Indonesia, Korea, Malaysia, Philippines, and Thailand). To ensure some consistency in the data, many of the macroeconomic fundamentals were taken from April 2007 and the June 2010 editions of the International Monetary Fund's International Financial Statistics CDROM. Other data were obtained from a variety of other sources. Forecasts for inflation and real GDP growth were taken from various editions of the International Monetary Fund's world Economic Outlook (available from www.imf.org). A drawback of the WEO data is that they are only available at the annual frequency. Hence, quarterly data were created via interpolation. ${ }^{8}$ Alternate forecast data, such as Consensus forecasts, were not available for all countries or for a sufficiently long span of data.

Timmermann (2006) discusses the performance of WEO forecasts and finds that they generally perform well and represent useful forecasts.

The requisite institutional data were taken either from the Polity IV dataset (www.cidcm.umd.edu/polity), or the Heritage Foundation (www.heritage.org). The central bank

\footnotetext{
${ }^{7}$ A separate appendix is available on request.

${ }^{8}$ Using the cubic last match average interpolation method. Beginning in 2007, forecasts are available semiannually for almost every country in the sample.
} 
transparency index is from Siklos (2010). The index is an aggregation of 15 objective characteristics that describe the type and content of information released by central banks. ${ }^{9}$ The 15 attributes are also aggregated into 5 different categories. They are: political transparency, which measures how open the central bank is about its policy objectives; economic transparency, an indicator of the type of information used in the conduct of monetary policy; procedural transparency, which provides an assessment of how monetary policy decisions are made; policy transparency, a measure of the content and how promptly decisions are made public by the central bank; and, finally, operational transparency which summarizes how the central bak evaluate its own performance.

In the empirical analysis to follow, I rely on the aggregate transparency index which is the (unweighted) sum of the codes assigned to the individual attributes that make up the index. Some data were collected from central bank websites through the BIS's central bank portal (www.bis.org), while the exchange rate classification scheme of Levy-Yeyati and Sturzenegger (LY-S; 2005) was also used. ${ }^{10}$ Data on external debt were obtained from the joint BIS-IMF-OECD-World Bank hub (devdata.worldbank.org/sdmx/jedh/jedg dbase.htm).

A popular alternative to estimating models of conditional volatility consists is using an estimate of the implied stock market volatility in the United States, as reported by the Chicago Bond Options Exchange $(\mathrm{CBOE})$, called the VIX, or volatility index. ${ }^{11}$ An appealing feature of this index is that it can be treated as being exogenous to emerging market economies. A potential drawback is that while the VIX has proved useful in studies at the daily sampling frequency, the merits of the index are possibly less clear-cut at the quarterly frequency. Data on foreign direct investment was obtained from UNCTAD

\footnotetext{
${ }^{9}$ The index of central bank transparency is the updated version of the Dincer andEichengreen (2007) index covering the period 1998-2006. The Dincer-Eichengreen index is itself inspired by the earlier attempt to quantify central bank transparency due to Eijffinger and Geraats (2004) and Siklos (2002).

${ }^{10}$ The LY-S data set ends in 2004. However, as far as I am aware, none of the exchange rate regimes (five way classification) for the countries in the sample changed after that date.

${ }^{11}$ Additional details about the construction of the VIX index can be found at http://www.cboe.com/micro/vix/.
} 
(stats.unctad.org/FDI/) and are used as an indirect indicator of the 'quality' of investments. ${ }^{12}$ Kaminsky and Reinhart (1999) argue that the behavior of domestic credit also plays a fundamental role in influencing the likelihood that a crisis of some kind will take place and, hence, it is plausible that yield spreads will also be affected. Consequently, I also consider a measure of domestic credit growth in the estimated specifications reported below.

The yield spread indicator frequently employed is the EMBI+ series while CDS spreads, available for only a subset of countries, and used far less frequently in studies of the kind conducted here, are also employed. ${ }^{13}$ The EMBI+ is constructed by J.P. Morgan (Morgan 1999, 2001) and represents a composite indicator of yield spreads for a large number of emerging markets that has been used in most studies of the determinants of emerging market bond yields. ${ }^{14}$ The resulting spread is calculated relative to benchmark U.S. Treasury bond yields. Since the maturity structure of the financial instruments covered in the $\mathrm{EMBI}+$ index is variable, an alternative that might be more useful in helping identify the extent to which yield spreads respond to forward-looking indicators such as macroeconomic forecasts or asset prices (e.g., stock returns) are credit default swap (CDS) spreads. These yields are for instruments with 5 years to maturity which are not only liquid but represent a large fraction of the sovereign CDS market (www.markit.com) . A CDS is a derivative contract in which a bondholder buys a guarantee that provides a form of insurance in the event of a default. In the event of a default the buyer receives an

\footnotetext{
${ }^{12}$ The FDI (flow) data are annual measured as a percent of GDP. See note 8 for the interpolation method used to convert the annual data to the quarterly frequency.

${ }^{13}$ Other proxies for emerging market yields have also been used by others. For example, Arora and Cerisola (2001) use individual country estimates of yield spreads based on Merrill Lynch's IGOV index and U.S. three month Treasury bills. Some (e.g., Ferrucci 2003) have used the EMBI global index. As one would expect there are pros and cons to using a particular definition of the yield spread. For example, a longer time series for the EMBI+ is available while, until recently, the EMBI Global Index covered a wider cross-section of countries. The EMBI+ is more heavily represented by Latin and South American countries while the issues covered by the EMBI Global index may not be as liquid as those incorporated in the EMBI+ index. Moreover, the EMBI+ composites control for floating coupons, principal collateral, or rolling interest guarantees. See www.jpmorgan.com.

${ }^{14}$ The EMBI+ monitors total returns for external debt instruments across emerging markets. The instruments include a variety of loan types, including Brady bonds, Eurobonds, and local instruments denominated in U.S. currency. Hence, foreign exchange risk is controlled for. The maturity for instruments represented is at least 2.5 years.
} 
amount equal to the difference between the face value of the defaulted bond and what can be obtained in markets based on an expectation of some kind of settlement (i.e., the recovery rate).

\subsection{Methodology}

As the previous discussion suggests two sets of determinants are thought to influence emerging market bond yield spreads. One set of factors is considered to be primarily of the domestic variety. These also include institutional variables such as the degree of central bank transparency or levels of corruption or fiscal independence. Another set of determinants is external, likely to originate in a key economy such as the U.S. Other variables of this kind can be thought of as factors that are global or external in nature in that they are likely to affect all merging markets. For example, oil prices or the extent to which the economy is open would also be included in this category. If we define the spread between emerging market bond yields, in country $i$ at time $t$, relative to benchmark U.S. Treasury bonds as $S P R E A D_{\text {it }}$, the basic specification can be written as

$$
\log \operatorname{SPREA} D_{i t}=\mu_{i}+X_{i t}^{\text {dom }} \beta_{i}^{\text {dom }}+X_{i t}^{e x t} \beta_{i}^{\text {ext }}+u_{i t}
$$

where $X_{\text {it }}$ are vectors of variables describing the domestic (dom), and external (ext), determinants of the spread. It has been commonplace to estimate specifications such as (1) by defining the dependent variable in log form (e.g., see Edwards 1984) owing to the form of the theoretical relationship between the spread and the probability of default. In the empirical analysis below this approach is also followed. However, as will be seen, the sample includes a significant period of declining spreads. Hence, first differencing of the spread is also considered. The vectors of determinants consist of the series previously discussed. These are written

$$
\begin{aligned}
& X_{i t}^{d o m}=\left(E R_{i t}, \pi_{i t}^{g a p}, W E O_{i t}^{j}, G^{\prime} O V_{i t}^{j}, O_{L} P_{t}\right) \\
& X_{i t}^{\text {ext }}=\left(\Delta F F R_{t}, E D_{i t}^{g a p}, \Delta O L_{t}, F I_{i t}, R^{g} S_{i t}^{g a p}, O P E N_{i t}, G F C_{t}\right)
\end{aligned}
$$


where $E R$ is an indicator of the type of exchange rate regime, $\pi^{g a p}$ is an estimate of the inflation gap, that is, inflation relative to some trend, ${ }^{15} D C^{\text {gap }}$ is the gap in domestic credit, WEO ${ }^{j}$ are the IMF's annual $^{\prime}$ forecasts of inflation $(\pi)$, real GDP growth $(\dot{y})$ and the balance of payments as a percent of GDP $(\dot{b})$ where $\mathrm{j}=\pi, \dot{y}, \dot{b}$. Finally, GOV ${ }^{j}$ stands for country specific institutional factors that proxy governance standards as represented by an indicator of corruption, fiscal independence, or central bank transparency. There exist several other governance type indicators. ${ }^{16}$ However, many of these are highly correlated with each other (results not shown). Hence, it would be inappropriate to include a large number of them in the same specification. It is in part for this reason that one set of estimates uses central bank transparency to proxy GOV while a separate set of results are based on the inclusion of the corruption and fiscal indicators. The OILP dummy captures the possibility, generally ignored in the empirical literature, that the evolution of yield spreads may be independently influenced according to whether the emerging market economy in question is an oil producer. In the present dataset this includes Mexico, Nigeria, Russia, and Venezuela. External determinants consist of the change in the U.S. Fed funds rate $(F F R)$, an indicator of U.S. monetary policy, while $E D$ is an indicator of the gross external debt position of country $i$, in U.S. dollar terms. ${ }^{17}$ Finally, OIL is a global indicator of world oil price inflation, FDI represent foreign direct investment flows (in U.S. dollar terms), RES are foreign exchange reserves, also denominated in U.S. dollars, while OPEN is the standard measure of the openness of an economy, proxied by the sum of exports and imports to GDP. Finally, as previously discussed, I also estimate a version of (1) by adding a dummy for the global financial crisis, set to one beginning in 2008Q1 and ending with the last observation, that is, 2009 Q4.

\footnotetext{
${ }^{15}$ Although many definitions of the trend are available I rely on an HP filter with a smoothing parameter of 1600. The pros and cons of such a filter are by now well-known, of course, but all available filters have their idiosyncrasies and flaws. Nevertheless, the HP filter is arguably the most widely used definition of the trend in a time series.

${ }^{16}$ Indeed, an earlier version of this paper (Siklos 2008) uses a variety of alternative proxies for GOV.

${ }^{17}$ Many of the determinants defined in U.S. dollar terms were also converted to percent of domestic GDP or in per capita terms.
} 
There are at least three omissions in equation (1). First, there is no explicit recognition of asymmetries for some of the determinants of the SPREAD, most notably in the case of inflation. One approach is to estimate equation (1) over, say, crisis and non-crisis samples or, alternatively, high versus low volatility periods. Such a strategy can potentially be useful, especially if there are legitimate concerns about the exogeneity of elements of $X_{i t}$ in (1). Unfortunately, however, there is the difficulty that the choice of volatility periods can be ad hoc or subject to selection bias while, in the case of crises, one has to choose which crisis to include and whether these are thought to be global in nature. A simpler approach is to differentiate between positive and negative values of some of the elements of $X_{i t}$ though, here too, there are problems that arise from the fact that a zero threshold may or may not be the correct one in defining the asymmetry. Nevertheless, this strategy is not only computationally convenient but is likely to be most parsimonious under the circumstances.

Second, there is no allowance made for the possibility that risk factors, generally speaking, can also interact with the SPREAD variable. These risk factors stem from changes in market views about future prospects of either individual or groups of emerging market economies. Indeed, it is often argued that one important common influence on emerging market bond yield spreads originates from the impact of volatility in the market for bonds (e.g., as in Baig and Goldfajn 2001, Edwards and Susmel 2001). At least two strategies are available to account for this concern. One study cited earlier, resorts to the Chicago Board Options Exchange (CBOE) volatility index, or VIX, which is the ticker symbol for this indicator. ${ }^{18}$ This index, used as a proxy for investor risk aversion, is a forward-looking indicator (30 days ahead) and, since it is based on a wide range of S\&P500 options, can justifiably be treated as an exogenous variable in a specification such as equation (1). Since the addition of the VIX requires only a trivial modification of equation (1) the details are not shown. For the purposes of estimation, and given the source of the VIX indicator, it is treated as an external determinant of yield spreads. Alternatively, a

\footnotetext{
${ }^{18}$ The first draft of this study also used the VIX. I thank an anonymous referee for pointing out that the present study is not the only one that resorts to this proxy.
} 
popular strategy is to estimate a model of conditional volatility relying on the GARCH family of models. In the panel setting, an important drawback of such models is that the number of estimated parameters rises very quickly with the number of dependent variable. The resulting 'curse of dimensionality' has led to proposals of simpler specifications, including the modified panel GARCH model of Cermeño and Grier (2005). In particular, the modified panel $\operatorname{GARCH}(1,1)$ model is based on the usual assumption of crosssectional independent errors but adds the assumption of a common GARCH process for all members of the panel. However, as discussed in the introduction, attempts to estimate various conditional volatility models were either unsuccessful or they did not provide any insights beyond the ones reported in the next section. ${ }^{19}$

Finally, to the extent that some of the determinants of SPREAD are attracted to each other in a statistical sense, namely in the form of a cointegrated relationship between some of the elements of $X_{i t}$, error correction terms have been omitted from equation (1). These considerations necessitate that equation (1) be estimated in the first difference form as shown below

$$
\Delta \log \operatorname{SPREAD} D_{i t}=\Omega_{i 0}\left[\mu_{i}+X_{i, t-1}^{K} \beta_{i}^{K}-\log \operatorname{SPREAD_{i,t-1}}\right]+\Omega_{i 1} \Delta X_{i, t-i}^{K}+\varepsilon_{i t}
$$

where the term in brackets is the error correlation term, and $K=$ dom and ext, all previously defined. Dailami, Masson and Padou (2005) resort to a similar specification and point out, among other considerations, that the number of estimated coefficients in a specification such as (2) can be large. Accordingly, they essentially rely on a multivariate version of the Engle-Granger two-step procedure wherein equation (1), or a more parsimonious version of it, is the cointegrated regression and the estimated residuals from that specification are substituted for the term in brackets in equation (2). There are well-known drawbacks with such a procedure. In addition, of course, it is not obvious which elements of $X^{k}$ are suitably cointegrated nor whether the typical span of data used to estimate such a

\footnotetext{
${ }^{19}$ For additional details and results relying on conditional volatility measures, see an earlier draft of this study (Siklos 2008).
} 
relationship is adequate to detect cointegration. As will be explained in the following section, conclusions were unaffected by the estimation of a model of the form (2) since evidence of unit roots and cointegration was, at best, mixed. ${ }^{20}$

\section{Empirical Results}

\subsection{Stylized Facts}

Figure 1 plots yield spreads based on both the EMB1+ and CDS data. The top left-hand figure combines all Latin and South American countries, the top right-hand side considers the European block of countries, while the remaining data for emerging markets in Africa and Asia are shown in the bottom left and right-hand corners of the figure. For the Latin and South American countries as well as the European group of countries in the sample the shaded areas represent years when, at least according to Kaminsky (2003), there was a financial crisis affecting some of the countries in the region (e.g., Russia, Argentina).

For the Asian block of countries, and other than the 2008-9 period, no crisis period is highlighted although it is widely agreed that the Asian crisis persisted through the end of 2008. Finally, to foreshadow some of the conclusions of this study, the period 2008Q1-2009Q4 highlights the episode of the global financial crisis which, as we shall see, had relatively more pronounced effects on Latin, South American, and European countries in the sample.

Although there are considerable differences in the spread behavior across countries, spreads display a negative trend throughout the second half of the sample, that is, beginning around 2002 until the middle of 2007, with the exception perhaps of Argentina. Needless to say, the global rise in bond spreads beginning around the third quarter of 2007, captures the worldwide turmoil in financial markets when the sub-prime market in the U.S. began to spread to other markets. Nevertheless, if one tests for

\footnotetext{
${ }^{20}$ This conclusion was unchanged in spite of the addition of data for the 2007-9 period. While the null of a unit root could not rejected as frequently as in an earlier version of the paper (see Siklos 2008) this is likely the result of the structural 'break' created by the events of 2008-9.
} 
common trends in the spreads via cointegration testing (not shown), together with other summary data discussed below, it is clear that the 22 countries considered in the sample can, in certain respects, also be treated as four separate blocks.

Figure 2 illustrates the diversity of the inflationary experience for a selection of countries in the dataset. The top portion of the Figure plots deviations in realized inflation from an HP filtered trend for countries whose average inflation rate was high throughout the sample relative to all emerging market economies considered. The bottom portion of the Figure plots the same information for a group of countries that had comparatively low average inflation rates throughout. Notice that there is considerable diversity in the inflationary experience among the high inflation countries considered. As far as the group of countries considered in the bottom portion of Figure 2, there is considerable volatility in inflation gaps throughout the sample considered. Finally, the inflationary experience of the countries shown in Figure 2 also appears to differ in terms of the peaks and troughs in inflation gaps. Similar patterns emerge for other key macroeconomic indicators such as the output gap (not shown).

Figure 3 plots the VIX proxy for risk aversion. Practitioners often consider values below 20 to be consistent with whetting investors' appetites for risk while values exceeding 30 are viewed as signaling considerable turbulence likely to raise considerably investors' aversion to risk. By this metric the calm that overtakes markets after 2002 is evident and may partly explain the decline in yield spreads observed in Figure 1. The VIX hovers mainly in neutral territory between 1998 and 2003, except in 2002 and, possibly, in later 1998. The latter reflects perhaps the ending of the Asian crisis. Of course, by early 2008, the VIX measure greatly exceeds the low volatility barrier and markets remain in a turbulent mode right up to the end of the sample with the period of the global financial crisis highlighted.

Next, Table 1 provides some summary statistics for the indicators of institutional quality described earlier. Variables such as openness, flows of foreign direct investment (FDI), central bank transparency, corruption levels, an indicator of fiscal autonomy, and the type of exchange rate regime, 
also reveal considerable diversity exists along these dimensions of economic performance. The sample also includes 11 countries that have a numerical inflation target. The relatively high transparency scores for these economies is quite noticeable from the data presented in Table $1 .{ }^{21}$ Notice also that there is a tendency for inflation targeting regimes to adopt either a pure float or some form of managed floating.

Next, Table 2 presents panel unit root and cointegration test results. Two sets of panel unit root tests are presented: the Im, Persaran, and Shin (2003; IPS) test as well as the Levin, Lin, and Chu (2002; LLC) test statistics. ${ }^{22}$ Relying on a $10 \%$ level of significance cutoff, there is evidence that the unit root null cannot be rejected for all countries in the sample, although the interpretation is sensitive to the test being used. Hence, the LLC more often tends to find that spreads are stationary while the IPS version of the unit root test does not. Taken together, the results point to the advisability of also examining the determinants of bond yields when the spread is specified in (log) levels and first differences (of the log levels). Nevertheless, the key conclusions of the empirical analysis discussed below are unaffected when the spread is specified in first differences. Consequently, to conserve space, results using the (log) spread only are presented. This also has the advantage of facilitating comparisons with the extant literature. In addition, results based on the estimated specification are also reported for individual blocks of countries listed in Table 2A, as a further check on the sensitivity of the results to changes in the specification.

\footnotetext{
${ }^{21}$ Most of the inflation targets were adopted in the late 1990s and early 2000s. see Siklos (2010, Table 1 ) for the precise dates. In large part because the relative differences in transparency match up quite well with the distinction between inflation and non-inflation targeting economies, a separate dummy variable that identifies the former type of policy regime is not considered.

${ }^{22}$ The literature of panel unit root tests is, of course, a large one. See, for example, Maddala and Kim (1998). Karlsson and Löttthgren (2000) show that the power of the LLC and IPS tests is affected by whether the factors of the cross-section that is stationary is large. This provides further justification for sub-dividing the panel into blocks of countries. It is useful to recall that the LLC test equation is written as

$\Delta y_{i t}=\mu_{i}+\beta y_{i, t-1}+\sum_{1}^{p} \phi_{k} \Delta y_{i, t-k}+\gamma t+\varepsilon_{i t}$

while the IPS test equation estimates $\beta_{i}, \gamma_{i}$, and $\phi_{i, k}$ in terms of the above specification. Hence, while the IPS test is based on individual unit root processes, the LLC test assumes a common unit root null.
} 
Part B of the Table reports panel cointegration tests between the yield spread and a few key variables that might be linked to it in the long run. ${ }^{23}$ For this purpose, I considered a measure of the external indebtedness, the degree of openness, international reserve holdings, and expected inflation. A theoretically motivated long-run relationship between these variables can be found from the literature previously surveyed. While some pairs of variables were found to be cointegrated, especially when the Asian group of countries is considered as well as when the entire dataset is considered, the results are decidedly more mixed than when the Latin, South American, European, and African economies are separately examined. Experimentation with various versions of equation (2) did not improve estimates or alter the conclusions discussed below. Accordingly, in the specifications reported below, I report only estimates of (1) and omit results based on panel error correction models.

\subsection{Econometric Estimates}

Tables 3 and 4 present the principal results. Table 3 includes a measure of central bank transparency while, in Table 4, levels of corruption and fiscal independence, substitute for the central bank transparency indicator. All estimates shown rely on the log of SPREAD as the dependent variable. The results are displayed over seven columns to permit an assessment of the sensitivity of the parameters to estimates by individual blocks of countries, as well as permitting for an asymmetric response to inflation expectations. Also considered, in the final column, is the impact of adding a dummy variable to capture the potential impact of the global financial crisis of 2008-9 on all countries in the dataset.

The first column of Table 3 provides estimates for a group that consists of 18 countries. Since no index of central bank transparency is available for four of the economies considered, the cross-section excludes Ecuador, Morocco, Nigeria, and Venezuela. In Table 4, the full set of 22 countries is considered. Domestic, external, and the VIX all significantly determine bond yield spreads. Among the forward

\footnotetext{
${ }^{23}$ The panel cointegration tests are based on an extension of the two-step Engle-Granger procedure due to Kao (1999) with cross-section specific intercepts but common coefficients in the first stage cointegrating test equation.
} 
looking variables (i.e., WEO forecasts) inflation and current account balance forecasts are highly significant across all regions with the notable exception of Asia. In the African and Asian groups of countries, the exchange rate regime also affects the yield spread. In African economies, the move towards a more flexible exchange rate signals a reduction in yield spreads but the opposite is true for the Asian block. In the case where inflation expectations are permitted to asymmetrically influence the yield spread, or when the entire dataset is considered and allowance is made for the impact of the global financial crisis, a move towards a less flexible exchange regime also signals a rise in the spread. It is likely that the results for Africa captures the benefits from anchoring domestic inflation to that of the U.S. whereas for Asia the coefficient reflects the risks from attempts to counteract the pressure from an appreciating exchange rate. Indeed, U.S. monetary policy is seen as having a separate and positive impact on yield spreads, especially in the Asian block. Otherwise, only the Latin and South American group of countries is significantly affected by changes in the U.S. fed funds rate.

Central bank transparency raises the yield spread in all of the specifications, with the exception of the Asian economies. The effect is highly significant and suggests that greater transparency, by permitting a more accurate assessment of the relative risks, has raised yields in all regions except Asia. In a sense then, it is conceivable that improvements in central bank transparency capture a premium that exists in emerging market bond yields over and above other indicators considered in the estimated specification. The VIX perhaps influenced by the long period of lessened risks in the world economy during the early 2000s, significantly but very modestly, reduced yield spreads. Once again, however, as is the case elsewhere, the opposite outcome is obtained for the Asian economies. Clearly, if there is any form of contagion, it is no longer evident from standard macroeconomic indicators. Instead, there is now more likely a form of volatility contagion which is reflected in the search for higher yields in emerging market economies. 
Two other interesting results in Table 3 are worth noting. First, the global financial crisis dummy is highly significant and, as might be expected, has raised yield spreads everywhere except for Asia and Africa. This reflects the 'flight to quality' phenomenon. In contrast, the results for Asia suggest that, perhaps temporarily, there was some decoupling by Asian (and African) economies, at least as perceived by yield spreads, from the other regions considered. Second, the widely reported accumulation of foreign exchange reserves across emerging markets contributes to higher spreads in Africa and Europe, again with the notable exception of Asia where the accumulation of reserves has served to narrow yield spreads, a reflection of the insurance motive behind such behavior.

Turning to Table 4, overall the conclusions are unaffected by the change in institutional quality indicator used. Fiscal autonomy and corruption typically have offsetting effects on the spread. Finally, notice that yield spreads are higher, other things equal, among the oil producers in the sample. It is possible that this captures a premium that may be more political in nature considering the countries included in this group. If we treat the economies in our sample as consisting of distinct regions, we find that the yield spread is, on average, significantly higher in Latin and South America relative to the European and African countries in the sample.

Attempts to estimate multivariate $\operatorname{GARCH}(1,1)$ models proved to be far less successful (results not shown). Although estimates were obtained for several of the country blocks considered earlier, the $\mathrm{ARCH}$ terms usually proved to be highly insignificant. Alternatives, such as higher order ARCH or EGARCH models, were also considered but then the curse of dimensionality proved to be a barrier to estimation. Although the resort to the VIX as a proxy for volatility proved exceedingly robust the inability to obtain comparable results using multivariate GARCH estimation is a disappointment. A variety of estimates that relax or modify the restrictions made in equation (3) proved unhelpful as well. The only consolation is that M-GARCH models have proved to be relatively difficult to estimate, especially for data at the sampling frequency considered in this paper (e.g., see the survey by Bauwens et al. 2006). Moreover, 
although GARCH and EGARCH models were estimated for individual countries (results not shown) it seems clear that the significance of the VIX in all cross-sections considered implies that there is a reasonably strong common element in the transmission of volatility across emerging market bond yield spreads.

\section{Conclusions}

This paper has considered some of the determinants of emerging market bond yield spreads for a sample of 22 countries that covers a period when these spreads were first on the decline followed by a sharp, albeit temporary, rise in reaction to the global financial crisis of 2008-9. A variety of determinants were considered, some domestic others external factors, still others more institutional in nature. Moreover, unlike what has typically been practiced in the extant literature, this study is also interested in the role played by forward-looking variables, such as inflation and other macroeconomic forecasts. Among the institutional factors central bank transparency plays a significant role in influencing emerging market yield spreads. Finally, consideration was given to the possibility of non-linearity in the determinants of bond yield spreads via asymmetric reaction to inflation expectations.

The results suggest that emerging markets cannot easily be treated as a single block. Nevertheless, there are few common determinants of yield spreads across all the markets considered such as volatility, proxied by the VIX indicator, central bank transparency, and the onset of the global financial crisis. Otherwise, there remain considerable idiosyncrasies across the four regions examined in this study such as the role of the exchange rate regime. Interestingly, U.S. monetary policy raises Latin and South American spreads as well as those in Asia region while openness of the economy raises yields in all regions except Europe which has seen its yield spread fall as a result. Whether expansion of the European Union plays a role is, however, unclear.

Some evidence of non-linearity was found but attempts to corroborate a robust influence coming from volatility via the estimation of multivariate $\mathrm{GARCH}$ models proved less successful. As a 
result, there is a clear direction forward for future research. First, a longer span of data might help decide with greater confidence whether some variant of the chosen specification, which nests all the ones used by other studies, ought to be estimated in levels or first differences, as well as whether omitted error correction terms should be added. Second, more research might reveal better or more precise forms of non-linearity than the simplistic specification considered in this study. Data limitations also prevented estimation with interaction terms that likely also play a role in influencing the course of yield spreads. Finally, alternative strategies to estimate multivariate conditional volatility models might also prove fruitful. The combination of too few panel observations, together with the need to estimate a large number of parameters, proved to be significant obstacles in obtaining useful results. 


\section{Figure 1 - Emerging Market Spreads, 1998-2009}
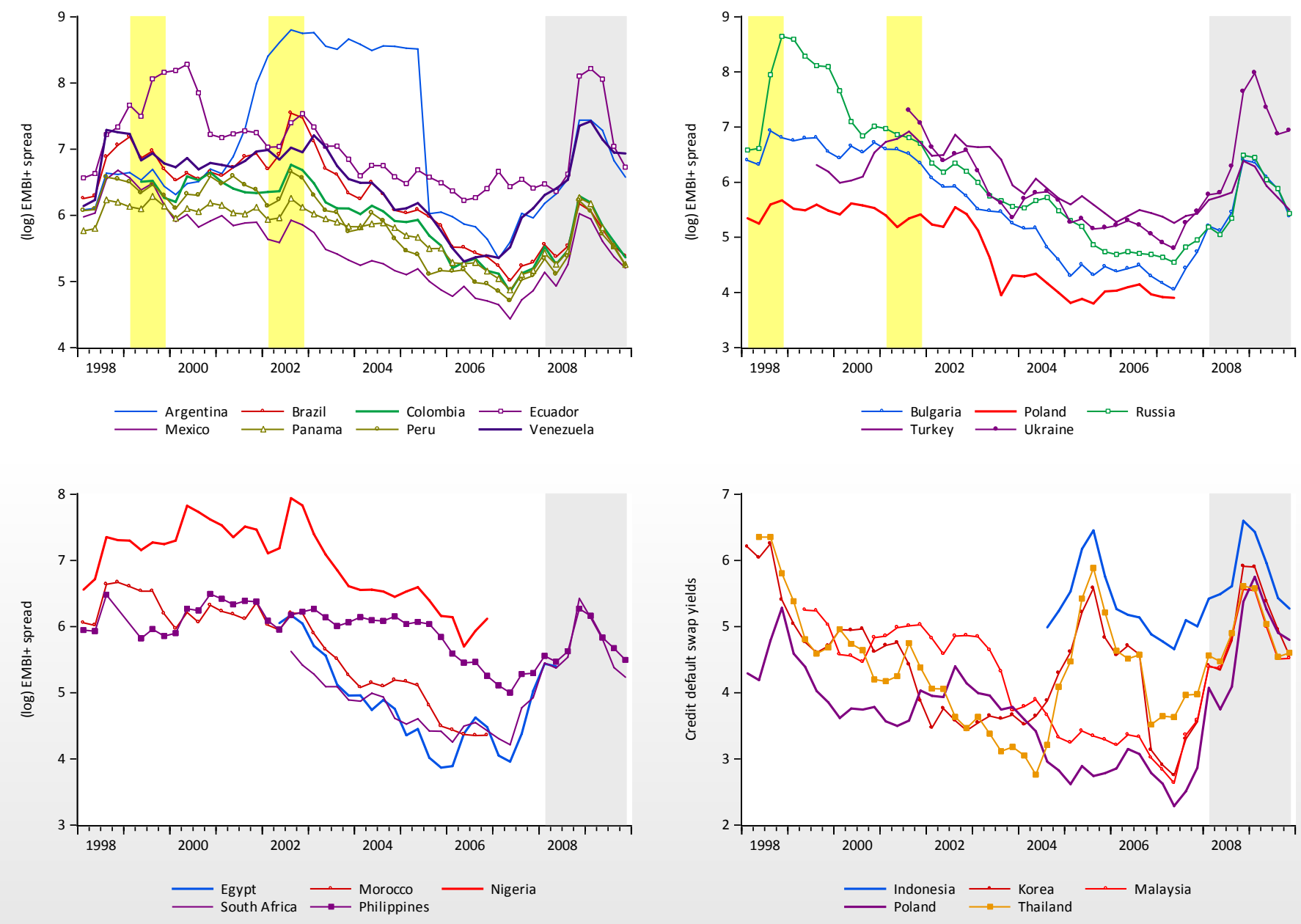

Note: Data sources and definitions are provided in the appendix. Data are quarterly. For Indonesia, Korea, Malaysia, Poland, and Thailand, yield spreads are based on CDS. Otherwise, EMBI yield spreads are used. The shaded areas are described in the main body of the paper. 
Figure 2 - Inflation Gaps for Selected Emerging Market Economies, 1998-2009
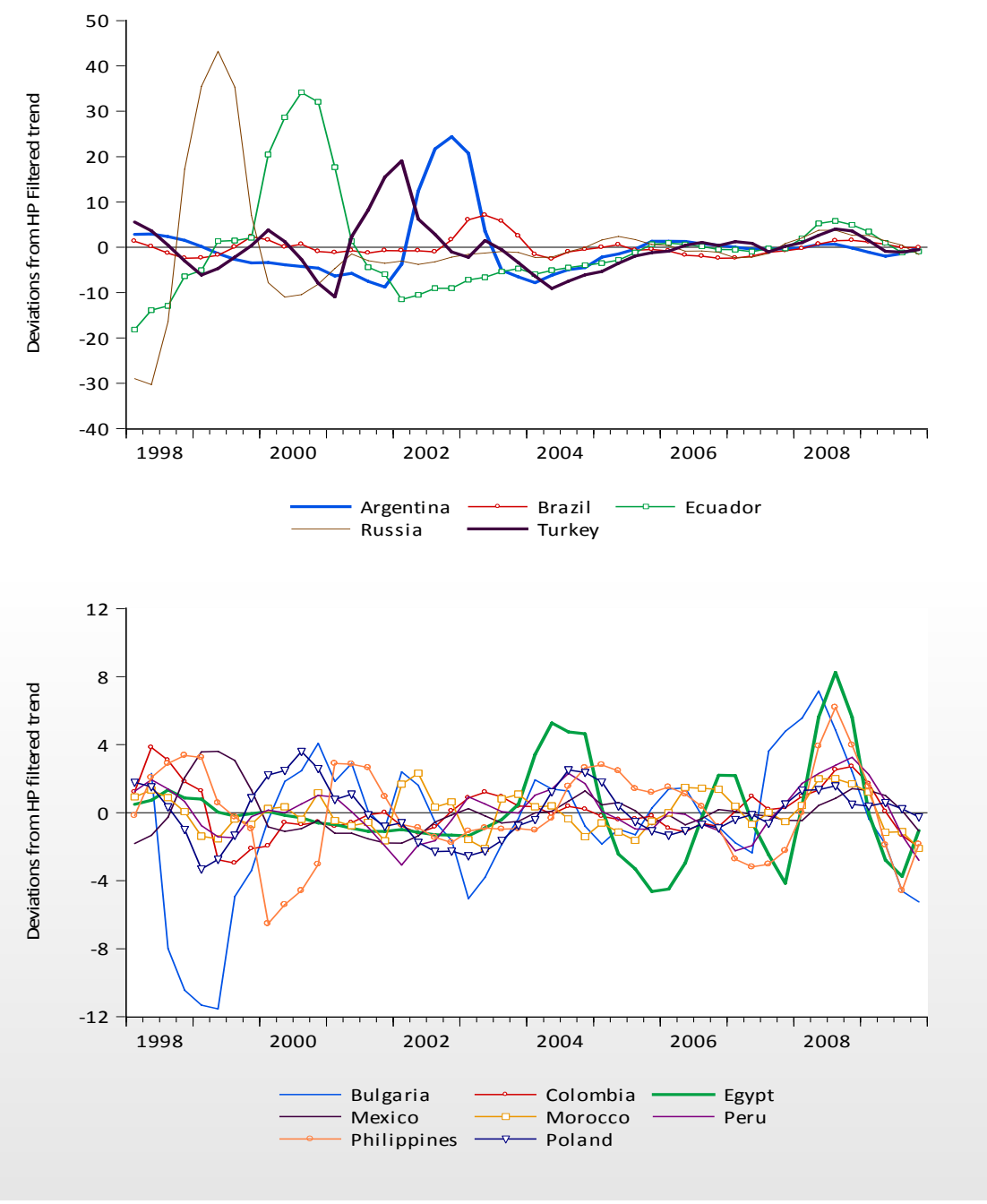

Note: Inflation (annual rate of change evaluated as 100 times $\left(\log P_{t}-\log P_{t-4}\right)$ ) less an HP filter (with smoothing parameter 1600) applied to inflation. Data are quarterly. 
Figure 3 - Volatility Index, 1998-2009

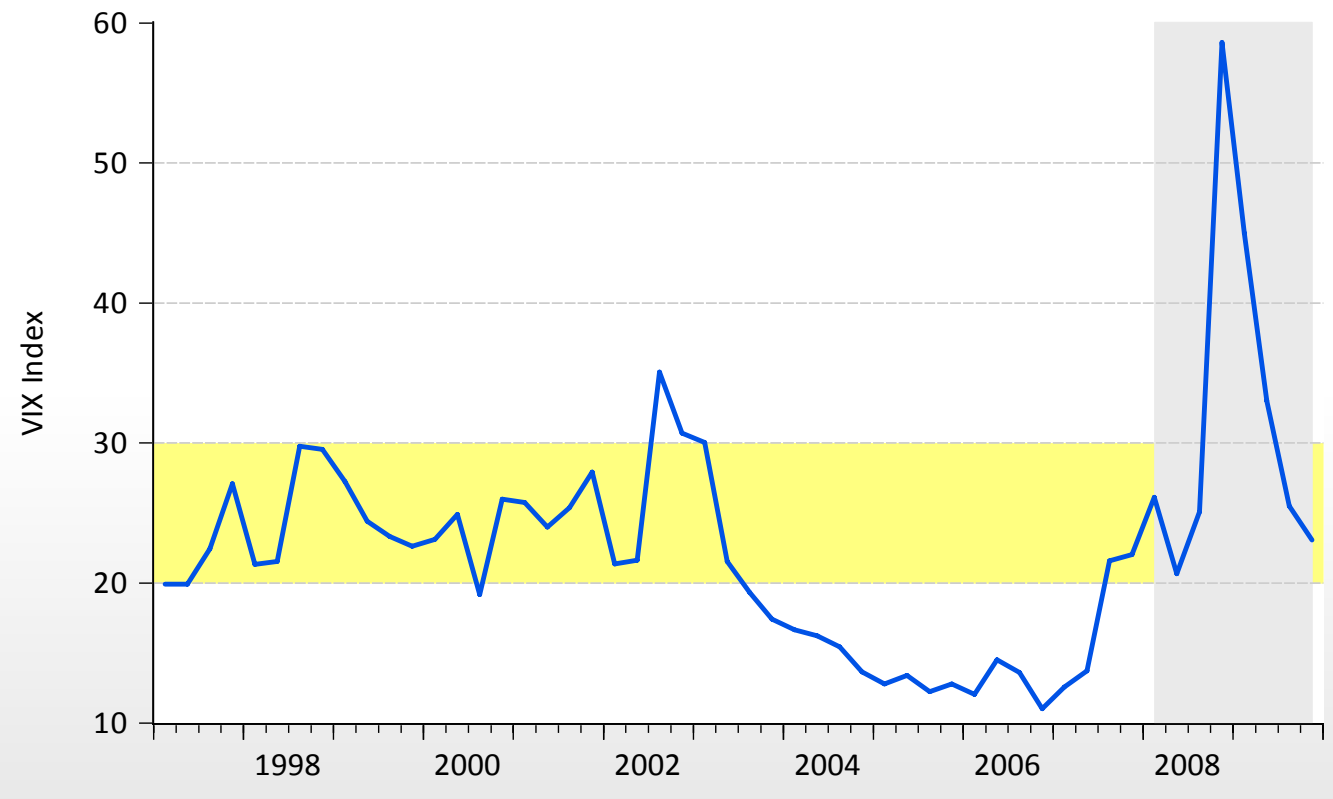

Note: Source and variable definition given in the text and in the appendix. Data are quarterly. The highlighted portions are also described in the text but values outside the horizontal shaded areas represent periods of excess volatility. The vertical shaded area represents the period of the 'global' financial crisis of 2008Q1-2009Q3. 
Table 1 - Selected Summary Statistics

\begin{tabular}{|l|c|c|c|c|c|c|}
\hline $\begin{array}{l}\text { Country } \\
\text { Inflation } \\
\text { Targeting) }\end{array}$ & $\begin{array}{c}\text { CB } \\
\text { Transparency }\end{array}$ & Openness & FDI & Corr. & Fiscal & $\begin{array}{c}\text { Exchange } \\
\text { rate } \\
\text { Regime }\end{array}$ \\
\hline Argentina & $5(3)$ & $7(2)$ & $3(2)$ & $46(19)$ & $81(5)$ & $3(1)$ \\
\hline Bulgaria & $5(.5)$ & $91(39)$ & $11(9)$ & $35(5)$ & $78(8)$ & $5(1)$ \\
\hline Brazil & $7(2)$ & $19(4)$ & $3(1)$ & $37(7)$ & $85(9)$ & $3(1)$ \\
\hline Colombia & $5(2)$ & $28(4)$ & $3(1)$ & $25(14)$ & $81(5)$ & $2(0)$ \\
\hline Ecuador & NA & $15(9)$ & $2(1)$ & $26(4)$ & $89(3)$ & $4(1)$ \\
\hline Egypt & $2(2)$ & $33(10)$ & $3(3)$ & $39(8)$ & $76(8)$ & $2(2)$ \\
\hline Indonesia & $6(2)$ & $52(13)$ & $1(2)$ & $24(11)$ & $79(2)$ & $3(1)$ \\
\hline Korea & $8(1)$ & $65(12)$ & $1(1)$ & $50(9)$ & $70(3)$ & $5(4)$ \\
\hline Malaysia & $5(1)$ & $92(31)$ & $4(2)$ & $59(10)$ & $85(2)$ & $5(1)$ \\
\hline Mexico & $5(1)$ & $13(1)$ & $3(1)$ & $42(7)$ & $82(2)$ & $2(0)$ \\
\hline Morocco & $\mathrm{NA}$ & $50(6)$ & $2(2)$ & $43(8)$ & $73(4)$ & $4(1)$ \\
\hline Nigeria & $4(.2)$ & $49(19)$ & $4(2)$ & $32(17)$ & $88(2)$ & $3(1)$ \\
\hline Panama & $\mathrm{NA}$ & $31(8)$ & $7(4)$ & $42(8)$ & $86(2)$ & $5(0)$ \\
\hline Peru & $7(1)$ & $31(8)$ & $4(1)$ & $33(6)$ & $86(3)$ & $3(1)$ \\
\hline Philippines & $7(3)$ & $83(17)$ & $2(1)$ & $27(4)$ & $82(3)$ & $3(1)$ \\
\hline Poland & $6(3)$ & $54(13)$ & $4(1)$ & $45(9)$ & $73(5)$ & $2(0)$ \\
\hline Russia & $2(1)$ & $48(7)$ & $2(1)$ & $27(4)$ & $86(6)$ & $3(1)$ \\
\hline South Africa & $7(2)$ & $12(2)$ & $2(1)$ & $44(7)$ & $75(3)$ & $2(0)$ \\
\hline Thailand & $6(3)$ & $97(19)$ & $4(1)$ & $43(18)$ & $74(.4)$ & $2(1)$ \\
\hline Turkey & $6(3)$ & $38(6)$ & $1(1)$ & $37(12)$ & $74(.5)$ & $2(1)$ \\
\hline Ukraine & $3(1)$ & $22(3)$ & $3(2)$ & $26(5)$ & $75(13)$ & $4(2)$ \\
\hline Venezuela & $\mathrm{NA}$ & $12(3)$ & $2(2)$ & $18(7)$ & $81(4)$ & $5(1)$ \\
\hline
\end{tabular}

Note: Openness is (total exports + total imports) as a percent of nominal GDP. A higher number indicates greater openness. The fiscal independence is an indicator from the Heritage Foundation. Details about the construction of this index can be found at http://www.heritage.org/index/FiscalFreedom.aspx. Foreign direct investment refers to the rate of change in FDI flows from the UNCTAD database. The source for the data is provided in section 3.1. The corruption indicator shown here is also from the Heritage Foundation (see http://www.heritage.org/index/Freedom-from-Corruption.aspx for the details). The central bank transparency index is from Siklos (2010). The exchange rate regime indicator is from Levy-Yeyati and Sturzenegger (2005), updated as explained in the text (1=inconclusive; $2=$ float; 3 = dirty float; $4=$ crawling peg; 5 =fixed). Countries with a numerical inflation target are shown in italics. Standard errors and figures are rounded to conserve space. NA means data are not available. 
Table 2 - Preliminary Testing

A. Panel Unit Root Tests (Null hypothesis: unit root)

\begin{tabular}{|l|c|c|}
\hline Group & \multicolumn{2}{|c|}{ Test Statistics } \\
\hline & IPS & LLC \\
\hline SPREAD: Asia & $-1.42(.08)$ & $-0.25(.40)$ \\
\hline SPREAD: All countries & $0.50(.69)$ & $-2.08(.02)$ \\
\hline SPREAD: Latin America & $1.95(.97)$ & $-0.95(.17)$ \\
\hline SPREAD: Latin America (large) & $0.71(.76)$ & $-0.66(.26)$ \\
\hline SPREAD: Europe & $0.16(.56)$ & $-0.74(.22)$ \\
\hline SPREAD: Africa & $-0.12(.45)$ & $-2.76(.01)$ \\
\hline
\end{tabular}

\section{B. Panel Cointegration (Null hypothesis: no cointegration)}

\begin{tabular}{|l|c|c|c|c|}
\hline Group & \multicolumn{4}{|c|}{ Cointegrating Relationships } \\
\hline & [SPREAD, ED] & [SPREAD, OPEN] & [SPREAD, RES] & [SPREAD, WEO ${ }^{\pi}$ ] \\
\hline SPREAD: Asia & $-3.28(.00)$ & $-3.39(.00)$ & $-3.74(.00)$ & $-3.26(.00)$ \\
\hline SPREAD: All countries & $-3.26(.00)$ & $-4.95(.00)$ & $-6.56(.00)$ & $-4.78(.00)$ \\
\hline SPREAD: Latin America & $0.01(.50)$ & $-0.07(.47)$ & $-1.96(.03)$ & $-0.23(.40)$ \\
\hline SPREAD: Latin America (large) & $-0.19(.42)$ & $-0.88(0.19)$ & $-1.29(.10)$ & $-1.03(.15)$ \\
\hline SPREAD: Europe & $-1.18(.12)$ & $-1.57(.06)$ & $-3.06(.00)$ & $-1.80(.04)$ \\
\hline SPREAD: Africa & $0.25(.40)$ & $-0.48(.32)$ & $-2.26(.01)$ & $-0.02(.49)$ \\
\hline
\end{tabular}

Note: SPREAD is EMBI+ data or CDS data as explained in the test, in Figure 1, and in the appendix. IPS is the Im, Pesaran and Shin test; LLC is the Levin, Lin and Chu test. See, for example, Maddala and Kim (1998), for additional details. The IPS test statistic is the W-test statistic while the $p$-value given in parentheses is based on the normal approximation. The average augmented Dickey-Fuller t-statistic is shown in brackets. The panel cointegration test relies on Kao's (1999) version of the Engle-

Granger two-step method applied to a panel. p-values are given in parenthesis. The appendix provides a list of countries included in each country blocks. 
Table 3 - Determinants of Emerging Market Bond Yield Spreads, 1997-2009

Dependent Variable: log SPREAD

\begin{tabular}{|c|c|c|c|c|c|c|c|}
\hline $\begin{array}{l}\text { Independent } \\
\text { Variables }\end{array}$ & All Countries & Africa & $\begin{array}{l}\text { Latin \& South } \\
\text { America }\end{array}$ & Europe & Asia & Asymmetric & $\begin{array}{l}\text { Global Financial } \\
\text { Crisis }\end{array}$ \\
\hline \multicolumn{8}{|c|}{ DOMESTIC } \\
\hline$\pi^{\text {gap }}$ & $0.001(.005)$ & $0.004(.005)$ & $0.022(.006)^{*}$ & $-0.004(.002)+$ & $-0.008(.026)$ & $-0.005(.004)$ & $0.004(0.003)$ \\
\hline ER & $0.014(.014)$ & $-0.167(.026)^{*}$ & $0.027(.023)$ & $-0.017(.021)$ & $0.236(.089)^{*}$ & $0.041(.015)^{*}$ & $0.041(.015)^{*}$ \\
\hline $\mathrm{DC}^{\text {gap }}$ & $-0.428(.240)+$ & $0.182(.145)$ & $-0.722(.197)^{*}$ & $-0.006(.314)$ & $-1.876(1.48)$ & $-0.570(.226)^{*}$ & $-0.524(.224)^{* *}$ \\
\hline WEO $^{\pi}$ & $-0.0003(.001)$ & $-0.010(.005)^{* *}$ & $-0.040(.003)^{*}$ & $-0.0007(.0004)+$ & $0.004(.039)$ & - & $-0.0001(.001)$ \\
\hline$\left(\pi-\mathrm{WEO}^{\pi}\right)>0$ & - & - & - & - & - & $0.002(.003)$ & - \\
\hline$\left(\pi-\right.$ WEO $\left.^{\pi}\right)<0$ & - & - & - & - & - & $-0.001(.001)$ & - \\
\hline WEO $^{y}$ & $0.001(.006)$ & $-0.031(.011)$ & $-0.021(.006)^{*}$ & $0.007(.006)$ & $-0.081(.020)^{*}$ & $-0.001(.006)$ & $0.0006(.0006)$ \\
\hline WEO $^{b}$ & $-0.012(.004)^{*}$ & $-0.088(.004)^{* *}$ & $-0.018(.005)^{*}$ & $-0.017(.006)^{*}$ & $-0.017(.017)$ & $-0.013(.004)^{*}$ & $-0.013(.004)^{*}$ \\
\hline CORRuption & - & - & - & - & - & - & - \\
\hline FISCAL & - & - & - & - & - & - & - \\
\hline TRANSPARENCY & $0.039(.008)^{*}$ & $0.385(.102)^{*}$ & $0.057(.017)^{*}$ & $0.078(.017)^{*}$ & $0.050(.040)$ & $0.023(.007)^{*}$ & $0.022(.007)^{*}$ \\
\hline \multicolumn{8}{|c|}{ EXTERNAL } \\
\hline$\Delta$ fed funds & $0.0002(.05)$ & $0.006(.061)$ & $0.083(.034)^{*}$ & $0.075(0.055)$ & $0.265(.112)^{* *}$ & $0.093(.045)^{* *}$ & $0.094(.044)$ \\
\hline $\mathrm{ED}^{\mathrm{gap}}$ & $-0.017(.047)$ & $-0.008(.038)$ & $0.021(.037)$ & $0.055(.057)$ & $0.032(.187)$ & $0.009(.041)$ & $0.014(.041)$ \\
\hline OIL & $-0.001(.001)$ & $-0.002(.001)$ & $-0.002(.0009)^{*}$ & $-0.001(0.002)$ & $-0.0008(.00)$ & $-0.003(.001)^{*}$ & $-0.003(.001)^{*}$ \\
\hline OPEN & $0.010(.001)^{*}$ & $0.002(.002)$ & $0.035(.005)^{*}$ & $-0.006(0.003)^{* *}$ & $-0.002(.005)$ & $0.009(.001)^{*}$ & $0.010(.001)^{*}$ \\
\hline FDI & $0.023(.007)^{*}$ & $-0.050(.011)^{*}$ & $-0.035(.012)^{*}$ & $0.022(.008)^{*}$ & $0.185(.066)^{*}$ & $0.011(.007)+$ & $0.010(.007)$ \\
\hline $\mathrm{RES}^{\text {gap }}$ & $0.152(.139)$ & $0.368(.099)^{*}$ & $0.166(.145)$ & $0.268(.148)+$ & $-1.528(.663)^{* *}$ & $-0.149(.123)$ & $-0.101(.119)$ \\
\hline GFC & - & $0.094(.115)$ & $0.319(.054)^{*}$ & $0.406(.105)^{*}$ & $0.143(.178)$ & $0.458(.062)^{*}$ & $0.451(.061)^{*}$ \\
\hline \multicolumn{8}{|c|}{ VOLATILITY } \\
\hline $\mathrm{VIX}$ & $-0.001(.003)$ & $-0.005(.003)$ & $-0.011(.00)^{*}$ & $-0.004(.004)$ & $0.037(.008)^{*}$ & $-0.009(.003)^{*}$ & $-0.009(.003)^{*}$ \\
\hline \multicolumn{8}{|c|}{ REGIONS } \\
\hline $\mathrm{C}$ & $3.498(.165)^{*}$ & $4.231(.407)^{*}$ & $4.919(.146)^{*}$ & $4.98(.219)^{*}$ & $2.732(.710)^{*}$ & $3.693(.160)^{*}$ & $3.680(.160)^{*}$ \\
\hline L\&SA & $1.349(.117)^{*}$ & - & - & - & - & $1.328(.112)^{*}$ & $1.345(.111)^{*}$ \\
\hline EUROPE & $1.014(.098)^{*}$ & - & - & - & - & $0.996(.094)^{*}$ & $1.015(.094)^{*}$ \\
\hline AFRICA & $0.889(.111)^{*}$ & - & - & - & - & $0.858(.106)^{*}$ & $0.874(.106)^{*}$ \\
\hline OIL producers & $0.328(.052)^{*}$ & - & - & - & - & $0.311(.046)^{*}$ & $0.312(.046)^{*}$ \\
\hline \multicolumn{8}{|c|}{ SUMMARY STATS } \\
\hline $\bar{R}^{2}$ & 0.43 & 0.90 & 0.87 & 0.81 & 0.58 & 0.52 & 0.52 \\
\hline$F$ (p-value) & $30.16(.00)$ & $49.41(.00)$ & $90.10(.00)$ & $47.37(.00)$ & $13.80(.00)$ & $37.87(.00)$ & $40.18(.00)$ \\
\hline Redundant FE & - & $78.66(.00)$ & $49.72(.00)$ & $74.73(.00)$ & $8.69(.00)$ & - & - \\
\hline OBS & 722 & 88 & 245 & 212 & 177 & 694 & 722 \\
\hline Cross-sections & 18 & 3 & 5 & 5 & 5 & 18 & 18 \\
\hline
\end{tabular}

Notes: Gap variables ( $\pi, D C$ ) are estimated via an HP filter, as explained in the text. ER is the exchange rate regimes of Levy-Yeyati and Sturzenegger (2005). All other variable definitions are constrained in the appendix. ${ }^{*}, *$ denotes statistical significance at the $1 \%$ and $5 \%$ levels, respectively. All estimates are GLS estimates using cross-section weights and heteroskedasticity adjusted standard errors. 
Table 4 - Determinants of Emerging Market Bond Yield Spreads, 1997-2009

Dependent Variable: log SPREAD ${ }_{\text {it }}$

\begin{tabular}{|c|c|c|c|c|c|c|c|}
\hline $\begin{array}{l}\text { Independent } \\
\text { Variables }\end{array}$ & All Countries & Africa & $\begin{array}{l}\text { Latin \& South } \\
\text { America }\end{array}$ & Europe & Asia & Asymmetric & $\begin{array}{l}\text { Global Financial } \\
\text { Crisis }\end{array}$ \\
\hline \multicolumn{8}{|c|}{ DOMESTIC } \\
\hline$\pi^{\text {gap }}$ & $0.006(.003)^{* *}$ & $0.002(.002)$ & $0.015(.003)^{*}$ & $-0.002(.004)$ & $0.008(.026)$ & $-0.004(.003)$ & $0.004(.003)$ \\
\hline ER & $0.081(.009)^{*}$ & $-0.073(.011)$ & $0.002(.016)$ & $-0.031(.027)$ & $0.411(.088)^{*}$ & $0.10(.01)^{*}$ & $0.104(.009)^{*}$ \\
\hline $\mathrm{DC}^{\mathrm{gap}}$ & $-0.741(.145)^{*}$ & $0.063(.061)$ & $-0.560(.168)^{*}$ & $0.236(.287)$ & $-2.29(1.28)+$ & $-0.86(.17)^{*}$ & $-0.753(.137)^{*}$ \\
\hline WEO $^{\pi}$ & $-0.001(.0005)+$ & $0.001(.003)$ & $-0.021(.001)^{*}$ & $0.0004(.001)$ & $-0.023(.035)$ & - & $-0.001(.0005)$ \\
\hline$\left(\pi-\mathrm{WEO}^{\pi}\right)>0$ & - & - & - & - & - & $0.002(.003)$ & - \\
\hline$\left(\pi-\right.$ WEO $\left.^{\pi}\right)<0$ & - & - & - & - & - & $-0.001(.0007)+$ & - \\
\hline WEO $^{y}$ & $-0.001(.004)$ & $-0.017(.005)^{*}$ & $-0.003(.003)$ & $0.019(.006)^{*}$ & $-0.067(.022)^{*}$ & $-0.001(.004)$ & $-0.001(.004)$ \\
\hline WEO $^{b}$ & $-0.019(.003)^{*}$ & $0.006(.002)^{*}$ & $0.0004(.004)$ & $-0.018(.006)^{*}$ & $0.0003(.018)$ & $-0.01(.003)^{*}$ & $-0.016(.003)^{*}$ \\
\hline CORR & $-0.017(.001)^{*}$ & $-0.018(.001)^{*}$ & $0.013(.002)^{*}$ & $-0.012(.004)^{*}$ & $0.018(.006)^{*}$ & $-0.01(.001)^{*}$ & $-0.015(.001)^{*}$ \\
\hline FISCAL & $0.004(.003)+$ & $0.002(.003)$ & $-0.012(.005)^{*}$ & $0.035(.006)^{*}$ & $-0.035(.033)$ & $0.01(.003)^{*}$ & $0.008(.002)^{*}$ \\
\hline TRANSP. & - & - & - & - & - & - & - \\
\hline \multicolumn{8}{|c|}{ EXTERNAL } \\
\hline$\Delta$ fed funds & $-0.095(.032)^{*}$ & $-0.107(.026)^{*}$ & $0.063(.033)+$ & $-0.062(.058)$ & $0.186(.109)+$ & $-0.01(0.03)$ & $-0.009(.030)$ \\
\hline$E D^{\text {gap }}$ & $0.051(.033)$ & $0.003(.017)$ & $-0.002(.035)$ & $0.062(.006)$ & $0.201(.168)$ & $0.02(.04)$ & $0.033(.031)$ \\
\hline OIL & $-0.001(.001)$ & $-0.0004(.001)$ & $-0.004(.001)^{*}$ & $-0.002(.002)$ & $0.006(.003)$ & $-0.003(.005)$ & $-0.003(.001)^{*}$ \\
\hline OPEN & $0.098(.001)^{*}$ & $0.005(.001)^{*}$ & $0.016(.00)^{*}$ & $-0.011(.004)^{*}$ & $-0.00(.005)$ & $0.008(.001)^{*}$ & $0.01(.001)^{*}$ \\
\hline FDI & $0.006(.004)$ & $-0.002(.005)$ & $-0.018(.090)^{* *}$ & $0.005(.010)$ & $0.087(.060)$ & $-0.001(.005)$ & $-0.001(.004)$ \\
\hline $\mathrm{RES}^{\text {gap }}$ & $-0.052(.074)$ & $0.392(.064)^{*}$ & $-0.17(.080)^{* *}$ & $0.229(.172)$ & $-1.475(.63)^{* *}$ & $-0.28(.09)^{*}$ & $-0.224(.073)^{*}$ \\
\hline GFC & - & $0.048(.058)$ & $0.596(.063)^{*}$ & $0.847(.105)^{*}$ & $0.078(.192)$ & $0.60(.05)^{*}$ & $0.584(.043)^{*}$ \\
\hline \multicolumn{8}{|c|}{ VOLATILITY } \\
\hline VIX & $-0.009(.002)^{*}$ & $-0.01(.002)^{*}$ & $-0.023(.002)^{*}$ & $-0.014(.005)^{*}$ & $0.044(.007)^{*}$ & $-0.02(.002)^{*}$ & $-0.016(.002)^{*}$ \\
\hline \multicolumn{8}{|c|}{ REGIONS } \\
\hline $\mathrm{C}$ & $4.132(.248)^{*}$ & $6.161(.257)^{*}$ & $6.518(.415)^{*}$ & $3.54(.53)^{*}$ & $4.80(2.74)+$ & $3.83(.26)^{*}$ & $3.900(.238)^{*}$ \\
\hline L\&SA & $1.393(.078)^{*}$ & - & - & - & - & $1.28(.08)^{*}$ & $1.290(.071)^{*}$ \\
\hline EUROPE & $0.817(.071)^{*}$ & - & - & - & - & $0.78(.07)^{*}$ & $0.807(.062)^{*}$ \\
\hline AFRICA & $0.932(.070)^{*}$ & - & - & - & - & $0.88(.07)^{*}$ & $0.885(.065)^{*}$ \\
\hline OIL producers & $0.131(.035)^{*}$ & - & - & - & - & $0.12(.03)^{*}$ & $0.129(.029)^{*}$ \\
\hline \multicolumn{8}{|c|}{ SUMMARY STATS } \\
\hline $\bar{R}^{2}$ & 0.56 & 0.97 & 0.85 & 0.80 & 0.61 & 0.60 & 0.61 \\
\hline$F$ (p-value) & $58.99(.00)$ & $196.49(.00)$ & $88.15(.00)$ & $42.06(.00)$ & $14.22(.00)$ & $63.85(.00)$ & $69.32(.00)$ \\
\hline Redundant FE & - & $115.93(.00)$ & $84.80(.00)$ & $59.17(.006)$ & $11.92(.00)$ & - & - \\
\hline OBS & 865 & 124 & 360 & 208 & 173 & 865 & 865 \\
\hline Cross-sections & 22 & 4 & 8 & 5 & 5 & 22 & 22 \\
\hline
\end{tabular}

Note: See notes to Table 3. 


\section{References}

Andritzky, J., G. Bannister, and N. Tamirisa (2005), "The Impact of Macroeconomic Announcements on Emerging Market Bonds", IMF working paper 05/83.

Ammer, J., and F. Cai (2007), "Sovereign CDS and Bond Pricing Dynamics in Emerging Markets: Does the Cheapest-to-Deliver Option Matter?", International Finance Discussion Paper 912, Board of Governors of the US Federal Reserve, December.

Arora, V., and M. Cerisola (2001), "How Does U.S. Monetary Policy Influence Sovereign Spreads in Emerging Markets?", IMF Staff Papers, 48 (3): 474-498.

Baig, T. and I. Goldfajn (1999), "Financial Market Contagion in the Asian Crisis", IMF Staff Papers 46: 167195.

Bauwens, L., S. Laurent, and J. Rombouts (2006), "Multivariate GARCH Models: A Survey", Journal of Applied Econometrics 21: 79-109.

Bank for International Settlements (1999), Annual Report 1998 (Basel: Bank for International Settlements).

Bernanke, B. (2004), "The Great Moderation", remarks at the meetings of Eastern Economics Association, Washington, D.C., 20 February, available at www.federalreserve.gov.

Benelli, R., and S. Gauguly (2007), "Financial Linkages Between the United States and Latin America Evidence from Daily Data", International Monetary Fund working paper 07/262.

Calvo, G., L. Lerderman, and C. Reinhart (1996), "Inflows of Capital to Developing Countries in the 1990s", Journal of Economic Perspectives 10 (Spring): 123-39.

Calvo, G. (2003), "Explaining Sudden Stop, Growth Collapse, and BOP Crisis: The Case of Distortionary Output Taxes", IMF Staff Papers (Special Issue), 50: 1-20.

Carmeño, R., and K. Grier (2005), "Conditional Heteroskedasticity and Cross-Section Dependence in Panel Data: Monte Carlo Simulations and Examples", University of Oklahoma.

Chiang, T., B-N. Jeon, and H. Li (2007), "Dynamic Correlation Analysis of Financial Contagion: Evidence from Asian Markets", Journal of International Money and Finance 26 (November): 1206-28.

Christiano, L., C. Gust, and J. Roldos (2002), "Monetary Policy in a Financial Crisis", NBER working paper 9005.

Ciarlone, A., P. Piselli, and G. Trebischi (2007), "Emerging Markets Spread and Global Financial Conditions", working paper 637, Bank of Italy, June.

Dailami, M., P. Masson, and J.J. Padou (2005), "Global Monetary Conditions Versus Country-Specific Factors in the Determination of Emerging Market Debt Spreads", World Bank Development and Prospects Group working paper, May. 
Debelle, G., and L. Ellis (2005), "The Response of Financial Markets in Australia and New Zealand to News About the Asian Crisis", in Identifying International Financial Contagion: Progress and Challenges (Sydney: Reserve Bank of Australia): 150-87.

Dincer, N., and B. Eichengreen (2007), "Central Bank Transparency: Where, Why, and with What Effects?", NBER working paper 13003, March.

Dungey, M., R. Fry, and V. martin (2009), "Crisis Transmission and Contagion: Which Test to Use?", working paper, ANU, September.

Dungey, M., R. Fry, B. Gonzales-Hermosillo, and V. Martin (2005), "Sampling Properties of Contagion Tests", working paper, October.

Edwards, S. (1984), "LDC Foreign Borrowing and Default Risk: An Empirical Investigation 1976-1980", American Economic Review 74, 726-734.

Edwards, S. (1986), "The Pricing of Bonds and Bank Loans in International Markets: An Empirical Analysis of Developing Market Countries' Foreign Borrowing", European Economic Review 30.

Eichengreen, B., and A. Mody (2000), "What Explains Changing Spreads on Emerging Market Debt?", in S. Edwards (Ed.) Capital flows and the emerging economies: Theory, evidence, and controversies (Chicago: University of Chicago Press), pp. 107-34.

Eijffinger, S., and P. Geraats (2004), "How Transparent Are Central Banks?", European Journal of Political Economy 22: 1-21.

Ferrucci, G. (2003), Empirical Determinants of Emerging Market Countries Sovereign Bond Spreads", Bank of England working paper 205.

Forbes, K., and R. Rigobon (2002), "No Contagion, Only Interdependence: Measuring Stock Market Comovements", Journal of Finance 57 (October): 2223-2261.

Garcia-Herrero, A., and A. Ortiz (2004), "The Role of Global Risk Aversion in Explaining Latin American Sovereign Spreads, mimeo, Bank of Spain.

Grandes, M. (2003), "Convergence and Divergence of Sovereign Bond Spreads: Theory and Facts from Latin America", working paper, Delta, Paris.

Hamilton, J., and D.H. Kim (2002), "A Reexamination of the Predictability of Economic Activity Using the Yield Spread", Journal of Money, Credit and Banking 34 (May): 340-60.

Hartelius, K., K. Kashiwase, and L.E. Kodres (2008), "Emerging market Spread Compression: Is it Real or is it Liquidity?", IMF working paper 08/10, January.

Hesse, H., and N. Frank (2009), "Financial Spillovers to Financial Emerging Markets During the Global Financial Crisis", IMF working paper 09/104. 
Im, K.S., H. Pesaran, and Y. Shiu (2003), "Testing for Unit Roots in Heterogeneous Panels", Journal of Econometrics 115 (July): 53-74.

International Monetary Fund (2006), "Main Drivers of Emerging Bond Spreads: Fundamentals or External Factors?", Box 1.5, in Global Financial Stability Report (Washington, D.C.: Inernational Monetary Fund), pp. 28-31.

Kamin, S., and K. von Kleist (1999), "The Evolution and Determinants of Emerging Market Credit Spreads in the 1990s", working paper No. 68, Bank for International Settlements.

Kaminsky, G. (2003), “Varieties of Currency Crisis”, NBER working paper 10193, December.

Kaminsky, G., and C. Reinhart (1999), "The Twin Crises: The Causes of Banking and Balance of Payments Problems", American Economic Review 89 (June): 463-500.

Kao, C. (1999), "Spurious Regression and Residual-Based Tests for Cointegration in Panel Data", Journal of Econometrics 90 (May): 1-44.

Karlsson, S. and M. Löttgren (2000), "On the Power and Interpretation of Panel Unit Root Tests", Economics Letters 66: 249-55.

Levin, A., C.F. Lin, and J. Chu (2002), "Unit Root Tests in Panel Data: Asymptotic and Finite Sample Properties", Journal of Econometrics 108 (May): 1-24.

Levy-Yeyati, E., and F. Sturzenegger (2005), "Classifying Exchange Rate Regimes: Deeds versus Words", European Economic Review 49 (August): 1603-35.

Longin, F. and B. Solnik (2001), "Extreme Correlation of International Equity Markets", Journal of Finance 56 (April): 649-676.

MacNamara, W. (2007), "Emerging Economies Weather the Storm", Financial Times, 20 November.

Maddala, G., and I.M. Kim (1998), Unit Roots, Cointegration, and Structural Change (Cambridge: Cambridge University Press).

Masson, P., and M. Mussa (1995), "The Role of the Fund: Financing and Its Interactions with Adjustements and Surveillance", IM<F pamphlet series No. 50 (Washington, D.C.: International Monetary Fund).

Min, H.G., D-H. Lee, C. Nam, M-C. Park, and S-H. Nam (2003), "Determinants of Emerging Market Bond Spreads: Cross-Country Evidence", Global Finance Journal 14: 271-86.

Morgan, J.P. (2001), "The Emerging Markets Bond Index", available at http://www2.jpmorgan.com/MarketDatalnd/EMBI/embi.html.

Morgan, J.P. (1999), "Introducing the J.P. Morgan Emerging Market Bond Index Global (EMBI Global). 
Pericolli, M. and M. Skracia (2003), “A Primer on Financial Contagion”, Journal of Economic Surveys, 17 (40: 571-608.

Remolona, E., M. Scatigna, and E. Wu (2006), "The Pricing of Sovereign Risk in Emerging Markets: Fundamentals Versus Risk Aversion", working paper, Bank for International Settlements.

Rozada, M., and E. Levy-Yeyati (2006), "Global Factors in Emerging Market Spreads", working paper, Inter-American development Bank, \#552, May.

Rowland, P., and L. Torres (2004), "Determinants of Spread and Creditworthiness for Emerging Market Sovereign Debt: A Panel Data Study", working paper, Banco de la Republica, Colombia.

Sachs, J., A. Tornell, A. Velasco, G. Calvo, and R. Cooper (1996), "Financial Crises in Emerging Markets: The Lessons from 1995", Brookings Papers on Economic Activity 1: 147-215.

Sander, H. and S. Kleinmeier (2003), "Contagion and Causality: An Empirical Investigation of Four Asian Crisis Episodes", Journal of International Financial Markets, Institutions and Money. 13 (April): 171-86.

Siklos, P. (2002), The Changing Face of Central Banking (Cambridge: Cambridge University Press).

Siklos, P. (2008), “Determinants of Emerging Market Bond Spreads: Domestic, Global Factors, and Volatility", HKIMR working paper No. 18.

Siklos, P. (2010b), "Central Bank Transparency: Another Look", Applied Economics Letters (forthcoming).

Timmermann, A. (2006), "An Evaluation of the World Economic Outlook Forecasts", IMF working paper 06/59, March. 


\section{Country and Region List}

(22 Countries)

Latin and South America

Argentina (large)
Brazil (large)
Colombia
Ecuador
Mexico (large)
Panama
Peru
Venezuela
Europe
Bulgaria
Poland
Russia
Turkey
Ukraine
Africa
Egypt
Morocco
Nigeria
South Africa

Asia

Indonesia

Korea

Malaysia

Philippines

Thailand 


\begin{tabular}{|c|c|c|}
\hline $\begin{array}{l}\text { Series Definitions } \\
\Rightarrow \text { data transformations }\end{array}$ & Sample & Sources (original sampling frequency) \\
\hline $\begin{array}{l}\text { (1) ER - country name } \\
\text { (22 countries) }\end{array}$ & $(\mathrm{F})$ & $\begin{array}{l}\text { Levy-Yeyati \& Sturzenegger (2005) } \\
\text { index of exchange rate regimes (Index } \\
1 \text { to } 5 \text { ) (M) } \\
1=\text { inconclusive; } 2=\text { float; } 3=\text { dirty; } \\
4=\text { crawling peg; } 5=\text { fixed. }\end{array}$ \\
\hline $\begin{array}{l}\text { (2) INFGAP1 - country } \\
\text { name } \\
\text { ( } 22 \text { countries) }\end{array}$ & $(F)$ & $\begin{array}{l}\text { Annual inflation }-\mathrm{HP} \text { filtered annual } \\
\text { inflation ( } \lambda=1,600 \text { for quarterly data) } \\
\text { starting with } 97.01 \text { observation } \\
\text { (percent) (Q) }\end{array}$ \\
\hline $\begin{array}{l}\text { ( } 3 \text { ) SPREAD - country } \\
\text { name } \\
(22 \text { countries) } \\
\Rightarrow \text { Ispread; } d(\text { spread })^{2}\end{array}$ & $(\mathrm{~F})$ & $\begin{array}{l}\text { EMBI+ based spread }{ }^{4} \text { (b.p.), last } \\
\text { monthly observations used for } \\
\text { quarterly. In some cases CDS data are } \\
\text { used, see Figure 1. (M) }\end{array}$ \\
\hline $\begin{array}{l}\text { (4) } F X-\text { country name } \\
\text { (22 countries) } \\
\Rightarrow D L F X_{-} *\left[100 *\left(\ln X_{t}-\ln X_{t-}\right.\right. \\
\text { 4)] }\end{array}$ & $(\mathrm{F})$ & $\begin{array}{l}\text { Domestic currency price of U.S. dollars } \\
\text { (DCU) (M) }\end{array}$ \\
\hline $\begin{array}{l}\text { (5) RES - country name } \\
\text { (22 countries) } \\
\Rightarrow \text { DLRES_*[100*In } \mathrm{RES}_{\mathrm{t}}- \\
\left.\left.\text { In RES } \mathrm{R}_{\mathrm{t}-4}\right)\right]\end{array}$ & (F) & $\begin{array}{l}\text { Millions of U.S. dollars (M). Gap } \\
\text { measured via H-P filtering }(\lambda=1,600 \text { for } \\
\text { quarterly data). }\end{array}$ \\
\hline $\begin{array}{l}\text { (6) POP - country name } \\
\text { ( } 22 \text { countries) }\end{array}$ & $(F)$ & $\begin{array}{l}\text { Population (millions) (A) } \\
\text { Converted to }\end{array}$ \\
\hline $\begin{array}{l}\text { (7) EX- country name* } \\
(17(Q)+5(A))\end{array}$ & $(F)$ & $\begin{array}{l}\text { Exports F.O.B. }(Q+A) \\
\text { Millions US\$ } \\
\text { Converted to quarterly via } \\
\text { interpolation, see footnote } 8 .\end{array}$ \\
\hline $\begin{array}{l}\text { (8) IM - country name* } \\
(17(Q)+5(A))\end{array}$ & (F) & $\begin{array}{l}\text { Imports F.O.B. }(\mathrm{Q}+\mathrm{A}) \\
\text { Millions US\$ } \\
\text { Converted to to quarterly via } \\
\text { interpolation, see footnote } 8 \text {. }\end{array}$ \\
\hline $\begin{array}{l}\text { (9) ED - country name } \\
(18-(\text { COLOMBIA })) \\
\Rightarrow \mathrm{dln}, \mathrm{d}\end{array}$ & (F) & $\begin{array}{l}\text { Gross External Debt Position } \\
\text { US\$ millions (Q) }\end{array}$ \\
\hline $\begin{array}{l}\text { (10) GDP - country } \\
\text { name* } \\
(18(\mathrm{Q})+4(\mathrm{~A}))\end{array}$ & (F) & $\begin{array}{l}\text { Nominal GDP (Q). Interpolation as } \\
\text { described in footnote } 8 \text {. }\end{array}$ \\
\hline 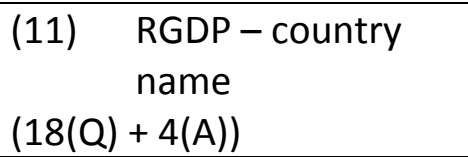 & (F) & Real GDP (2000 or $2005=100)$ \\
\hline
\end{tabular}




\begin{tabular}{|c|c|c|}
\hline $\begin{array}{l}\text { (12) WEO B - country } \\
\text { name } \\
\mathrm{P}-\text { country name } \\
\mathrm{Y} \text { - country name } \\
\text { (22 countries) }\end{array}$ & $(F)$ & $\begin{array}{l}\text { WEO forecasts ( } A \text {; semi-annual for most } \\
\text { beginning in 2007) } \\
B=\text { balance of payments } \\
P=\text { inflation } \\
Y=\text { economic growth } \\
\text { Converted to quarterly as explained in } \\
\text { footnote } 8 \text {. }\end{array}$ \\
\hline $\begin{array}{l}\text { (13) OIL } \\
\Rightarrow d \ln =100\left(\ln X_{t}-\ln X_{t-4}\right)\end{array}$ & $(F)$ & $\begin{array}{l}\text { Average crude price from IFS: world } \\
\text { spot price average index (M) }\end{array}$ \\
\hline $\begin{array}{ll}\text { (14) } & \text { VIX } \\
\text { (US) } & \end{array}$ & $(F)$ & VIX constructed from daily rate (D) \\
\hline $\begin{array}{l}\text { (18) FDI - country name } \\
\text { ( } 22 \text { countries) } \\
\Rightarrow \text { dln; } d\end{array}$ & $(F)$ & $\begin{array}{l}\text { FDI flows in millions of current US\$ (A) } \\
\text { Converted to quarterly as explained in } \\
\text { footnote } 8 \text {. }\end{array}$ \\
\hline $\begin{array}{l}\text { (19) } \\
\text { CORR, FIS } \\
\text { ( } 22 \text { Countries) }\end{array}$ & $(F)$ & $\begin{array}{l}\text { Indices corruption, and fiscal policy } \\
\text { quality, converted to quarterly as } \\
\text { explained in footnote } 8(A)\end{array}$ \\
\hline $\begin{array}{l}\text { (20) TI } \\
\text { (18 Countries; see text } \\
\text { for excluded countries) }\end{array}$ & $(F)$ & $\begin{array}{l}\text { Transparency index (A), from Dincer } \\
\text { and Eichengreen (2007) and Siklos } \\
\text { (2010b). Converted to quarterly as } \\
\text { explained in footnote } 8 \text {. }\end{array}$ \\
\hline
\end{tabular}

Notes: (F) means full sample used in estimation, 1998Q1 - 2009Q4 (after differencing and calculation of annual rates of change0. Raw data: $(\mathrm{M})$ - monthly; $(\mathrm{Q})$ - quarterly; (A) - annual; (D) - daily. All data converted to quarterly in generating econometric estimates.

1. For Panama, $E R=1$ throughout (=1 US\$); for Argentina $E R=1$ (=1 US\$) until 2002.

2. I variable-name, dl variable-name, d variable-name means log, log change, or first difference of variable created for the empirical analysis.

3. Other sources provided in the text. 